\title{
Morphological and biochemical properties of garlic (Allium sativum L.) collections
}

\author{
P C Tripathi*, H M Jadhav, A A Qureshi, V Sankar, V Mahajan \& K E Lawande \\ ICAR-Directorate of Onion and Garlic Research, Rajgurunagar-410 505, Dist. Pune (Maharashtra) \\ *E-mail: prakaashtripathii2000@yahoo.co.in
}

Received 02 November 2020; Revised 01 June 2021; Accepted 05 June 2021

\begin{abstract}
Garlic (Allium sativum L.) is an important constituent of many of traditional medicines. The nutrient composition and biochemical ingredients of garlic vary among varieties and locations. The current experiment was conducted with 35 genotypes of garlic to study variation in morphological and biochemical properties among these genotypes. The weight of bulbs ranged from $6.9 \mathrm{~g}$ to $22.6 \mathrm{~g}$. Highest number of clove bulb ${ }^{-1}$ was recorded in collection -286 (44.6) followed by GG-2 (40.6). Clove weight was higher in collection - 316 (1.41 g). The dry weight ranged from 28.6 per cent to 38.65 per cent. Highest total soluble solids were found in collection -79 (35.1 Brix). Potassium, iron and zinc content were higher in GG-2 (1.70\%, 47 ppm and 19.2 ppm, respectively). Sulphur and copper content were higher in G-41. Manganese content ranged from 6.90 to 23.1 ppm. Highest anthocyanin pigment was found in the peel of cv. Godavari (5.35 mg). There was not much difference in anthocyanin content in pulp of purple and white colour varieties. Pyruvic acid content ranged from $20.9 \mu \mathrm{mol} \mathrm{ml}^{-1}$ to $24.9 \mu \mathrm{mol} \mathrm{ml} \mathrm{m}^{-1}$. Over all cvs. G-50, G-41, collection -316 were found superior over others.
\end{abstract}

Keywords: analysis, collections, garlic, microelements

\section{Introduction}

Garlic (Allium sativum L.) is an integral part of most of the cuisines throughout the world. The crop is cultivated in about 1.5 million hectares with an annual global production of about 28.49 million metric tons (FAO 2018). Though originated in Central Asia, it is being cultivated in about 150 countries worldwide. China is the largest producer of garlic in the world and accounts for 78 per cent of total garlic production. India ranks second and produces
6 per cent of the total production. The average productivity of the garlic in the world is 13 tonnes but the productivity in China is more than 25 tonnes ha-1 (Gupta 2015). Rajasthan and Madhya Pradesh are the leading states in India contributing more than $50 \%$ in both area and production. The other major garlic growing states are Gujarat, Uttar Pradesh and Maharashtra (Anonymous 2018). Apart from its use in cuisine, garlic has historically been used to alleviate pains, leprosy, deafness, diarrhoea, constipation, parasitic infection, 
fever, stomach ache etc. since long (Woodward 1996; Tattelman 2005; Rana et al. 2011; Tripathi et al. 2013). More than 100 varieties of garlic and several hundred landraces of garlic are grown throughout the world. They are broadly classified as hard-neck and soft-neck. Most of the varieties grown in India are soft neck type. The cultivars vary in size, shape, colour, number of cloves bulb-1 ${ }^{-1}$ clove size etc. and in their storability because of their inherent dormancy. However, very little information is available on chemical composition of these varieties. Thus the current research was carried out to study morphological and biochemical variations among some garlic varieties and collections.

\section{Materials and methods}

Garlic varieties and collections used in the study were from germplasm collection of ICAR- Directorate of Onion and Garlic Research, Rajgurunagar, Pune, Maharashtra. Recommended cultural practices were followed for cultivation. Due care was taken to draw samples from same plots and at same maturity stage. Twenty-five bulbs of each collection were taken for observation and analysis.

\section{Morphological observations}

Cured bulbs were cleaned properly and extra roots were removed. The bulb weight, fruit length, fruit diameter was recorded using analytical balance and digital vernier calipers. Fruit shape and fruit colour were recorded as per standard fruit shape and colour charts. The bulbs were broken to record the number of cloves bulb ${ }^{-1}$. The total soluble solids were recorded using ERMA hand refractometer. The samples were peeled and cut into small pieces using a clean knife and used for various analyses.

\section{Ascorbic acid}

Ascorbic acid content of fruits (10 g pulp) was analyzed by Dichlorophenol-indophenol visual titration method. The ascorbic acid content was determined as per Ranganna (1986).

\section{Moisture and dry matter content}

One hundred gram fresh edible portion was used for estimation of moisture content and dry weight. The samples were air dried followed by oven drying for $48-72$ hours at $58{ }^{\circ} \mathrm{C}$ till the samples attained a constant weight. The dried samples were weighed and dry matter content calculated. The dried samples were powdered using a grinder fitted with stainless steel blades and stored in polythene bags for analysis.

\section{Pyruvic acid}

Pyruvic acid was estimated using the method described by Yoo et al. (1995) using 2, 4-dinitrophenylhydrazine (DNPH). The colour intensity was measured at $420 \mathrm{~nm}$. Standard graph was prepared using various concentrations of sodium pyruvate and colour intensity was plotted on a graph.

\section{Total anthocyanin content}

Total monomeric anthocyanin content was quantified using a $\mathrm{pH}$ differential method described by Giusti \& Wrolstad (2001). Samples were diluted in two buffer solutions: potassium chloride buffer $0.025 \mathrm{M}(\mathrm{pH} 1.0)$ and sodium acetate buffer $0.4 \mathrm{M}(\mathrm{pH} 4.5)$ and then the absorbance was measured simultaneously at $516 \mathrm{~nm}$ and $700 \mathrm{~nm}$ (to correct for haze) after 15 minutes of incubation at room temperature against distilled water as blank. A Jasco V $530 \mathrm{UV}-\mathrm{Vis}$ Spectrophotometer was used for measurement. The monomeric anthocyanin pigment concentration was calculated according to the following equation: $C$ (mg $\left.1^{-1}\right)=\mathrm{A} \times \mathrm{MW} \times \mathrm{DF} \times 1000 / \mathrm{E} \times 1$, Where: $\mathrm{A}=$ (A516-A700) at $\mathrm{pH} 1.0-(\mathrm{A} 516-\mathrm{A} 700)$ at $\mathrm{pH} 4.5$, $\mathrm{MW}$ is the molecular weight, DF is the dilution factor and 1 is the path length $(1 \mathrm{~cm})$. The total monomeric anthocyanin content was expressed as cyanidin-3-glucoside equivalents (MW=449.2 and $=s$ 26900). Each sample was analyzed in triplicate and the results were expressed as the average of the two measurements. 


\section{Analysis of mineral content}

Powdered (dried) samples were used for extracting nitrogen, phosphorus, potassium, calcium, magnesium, sulphur, iron, zinc, copper and manganese contents. Nitrogen in plant sample was determined as described by Piper (1966) after digestion with concentrated sulphuric acid. Phosphorus in the digested sample was estimated by vanadomolybdophosphoric yellow colour method (Piper 1966) by measuring absorbance at $490 \mathrm{~nm}$ using Spectrophotometer and expressed as uptake in $\mathrm{kg} \mathrm{ha}^{-1}$. The potassium concentration in plant sample was determined by flame photometric method (Piper 1966). Sulphur in plant sample was determined by turbidimetric method, following the procedure given by Piper (1966).

The content of $\mathrm{Cu}, \mathrm{Fe}, \mathrm{Mn}$ and $\mathrm{Zn}$ were estimated by using Atomic Absorption Spectrophotometer Piper (1966).

\section{Data analysis}

All the data were statistically analyzed by ANOVA (Panse \& Sukhatme 1995) considering the treatment as the independent variable. The means were separated by the Tukey's test $(\mathrm{P}<$ 0.05).

\section{Results and discussion}

\section{Bulb characteristics}

The bulb characters of garlic varieties and collections viz., bulb weight, equatorial diameter, polar diameter, neck thickness, no. of cloves/bulb, bulb shape and colour are given in Table 1. The average weight of bulbs ranged from $6.71 \mathrm{~g}$ to $22.6 \mathrm{~g}$. It was highest in G-50 (22.6 g) followed by collection- 316 (21.37 g), G-41 (18.7 g) and GG-2 (17.5 g). These were significantly higher than all other genotypes. The minimum weight of bulb was recorded in collection -260 (6.71 g). Highest equatorial diameter $(41 \mathrm{~mm})$ of bulb was recorded in collection - 177 and collection - 316 followed by G-50 (39.9 mm), GG-2 (39.1 $\mathrm{mm})$ and G-41
(37.2 mm). The lowest equatorial diameter was recorded in collection 260 which was 28 $\mathrm{mm}$. The highest polar bulb diameter was recorded in G-41 (27.4 $\mathrm{mm}$ ), followed by GG-2 $(27.2 \mathrm{~mm})$, collection- $316(27 \mathrm{~mm})$ and G-50 $(26.3 \mathrm{~mm})$. The number of cloves/bulb ranged from 9.6 to 44.6 . The highest cloves bulb ${ }^{-1}$ was recorded in collection-286 (44.6), GG-2 (40.6), collection-15 (28.9) while lower number of cloves bulb $^{-1}$ was recorded in collection-215 (9.6), collection-314 (10.9), collection-43 (12.28), collection-323 (18.40) and G-282 (20.4) (Table 1). Lesser number of cloves in collection-215, collection-314 and collection- 43 was due to poor development of bulbs which has confirmed by their low bulb weight. This may be due to climatic conditions as it is a well proven fact that bulb development in garlic is strongly influenced by temperature. The temperate garlic varieties /lines produced very small or no bulbs under tropical conditions (Danna et al. 2000; Yebirzaf Yeshiwas et al. 2018). The bulb shape was oblong in most of the collections and varieties. The bulbs were round in cvs. G-282, GG-2, GG-3, Collection-286, collection-326 and collection-227. The bulb colour was white in most of the genotypes. Collection-64, collection-179 and collection-326 had purple colour bulbs while DARL-50, collection-163 and collection-46 had pinkish white bulbs (Table 1). The neck thickness was higher in varieties and collections with bigger size bulbs.

\section{Clove characteristics}

The clove characters viz., length, girth, weight, colour and clove arrangement are given in Table 2. The clove weight ranged from $0.39 \mathrm{~g}$ to $1.41 \mathrm{~g}$ it was higher in collection- 316 (1.41 g), collection-177 (0.92 g), G-41 (0.82 g), G-50 (0.83 g), collection-109 (0.75 g) and G-323 $(0.75 \mathrm{~g})$. Lower clove weight was found in collection-15 (0.45 g), collection-163 (0.48 g) and collection-6 (0.51 g). The clove length ranged from $13.3 \mathrm{~mm}$ to $22.1 \mathrm{~mm}$. It was higher in collection-79 $(22.1 \mathrm{~mm})$ followed by G-41 (20.40 mm) and G-50 (19.5 mm). Lower clove length was recorded in collection-43 (13.30 $\mathrm{mm})$, GG-1 (14.8 $\mathrm{mm})$ and Godavari (15.50 
Table 1. Bulb characters of garlic varieties and collections

\begin{tabular}{|c|c|c|c|c|c|c|c|}
\hline $\begin{array}{l}\text { Variety/ } \\
\text { Collection No. }\end{array}$ & $\begin{array}{l}\text { Bulb } \\
\text { weight } \\
\text { (g) }\end{array}$ & $\begin{array}{l}\text { Equatorial } \\
\text { diameter } \\
(\mathrm{mm})\end{array}$ & $\begin{array}{l}\text { Polar } \\
\text { diameter } \\
(\mathrm{mm})\end{array}$ & $\begin{array}{l}\text { Neck } \\
\text { thickness } \\
(\mathrm{mm})\end{array}$ & $\begin{array}{l}\text { No. of } \\
\text { cloves/ } \\
\text { bulb }\end{array}$ & $\begin{array}{l}\text { Bulb } \\
\text { shape }\end{array}$ & $\begin{array}{l}\text { Bulb } \\
\text { colour }\end{array}$ \\
\hline G1 & 10.10 & 29.50 & 23.10 & 4.00 & 25.00 & Oblong & white \\
\hline G41 & 18.70 & 37.20 & 27.40 & 4.00 & 21.60 & Round & white \\
\hline G50 & 22.60 & 39.90 & 26.30 & 5.00 & 25.70 & Oblong & white \\
\hline G282 & 12.70 & 33.70 & 23.20 & 4.00 & 20.50 & Round & white \\
\hline G323 & 15.60 & 36.10 & 25.90 & 4.00 & 18.40 & Oblong & white \\
\hline GG2 & 17.50 & 39.10 & 27.20 & 5.00 & 40.60 & Round & white \\
\hline GG3 & 11.10 & 32.90 & 22.10 & 4.00 & 27.90 & Round & white \\
\hline Godavari & 10.90 & 33.50 & 23.10 & 4.00 & 18.30 & Oval & Purple \\
\hline DARL50 & 15.70 & 36.30 & 25.00 & 4.00 & 26.60 & Oblong & Pinkish white \\
\hline Collection 4 & 9.46 & 32.00 & 23.00 & 4.00 & 13.10 & Oblong & White \\
\hline Collection 6 & 10.50 & 33.00 & 21.00 & 4.00 & 31.20 & Oblong & White \\
\hline Collection 15 & 8.71 & 33.00 & 24.00 & 4.00 & 28.90 & Oblong & White \\
\hline Collection 43 & 12.28 & 33.00 & 25.00 & 4.00 & 12.28 & Oblong & White \\
\hline Collection 46 & 10.46 & 32.00 & 23.00 & 4.00 & 23.40 & Oblong & Pinkish white \\
\hline Collection 64 & 12.07 & 34.00 & 23.00 & 4.00 & 15.60 & Oblong & Purple \\
\hline Collection 79 & 12.06 & 34.00 & 23.00 & 3.00 & 17.60 & Oblong & White \\
\hline Collection 109 & 11.44 & 33.00 & 23.00 & 4.00 & 17.90 & Round & White \\
\hline Collection 162 & 13.76 & 38.00 & 27.00 & 5.00 & 22.20 & Oblong & White \\
\hline Collection 163 & 6.90 & 29.00 & 23.00 & 4.00 & 19.30 & Oblong & Pinkish white \\
\hline Collection 177 & 12.72 & 41.00 & 23.00 & 4.00 & 17.30 & Oblong & Purple \\
\hline Collection 215 & 8.73 & 30.00 & 21.00 & 4.00 & 9.60 & Oblong & White \\
\hline Collection 224 & 9.48 & 30.00 & 21.00 & 4.00 & 22.80 & Round & White \\
\hline Collection 227 & 10.41 & 31.00 & 21.00 & 4.00 & 27.70 & Round & White \\
\hline Collection 260 & 6.71 & 28.00 & 20.00 & 4.00 & 19.63 & Oblong & White \\
\hline Collection 273 & 11.67 & 29.00 & 19.00 & 3.00 & 16.50 & Oblong & White \\
\hline Collection 279 & 10.14 & 33.00 & 24.00 & 3.00 & 13.90 & Oblong & White \\
\hline Collection 286 & 7.76 & 29.00 & 19.00 & 3.00 & 44.60 & Round & White \\
\hline Collection 294 & 8.61 & 30.00 & 20.00 & 4.00 & 26.90 & Oblong & White \\
\hline Collection 301 & 10.87 & 33.00 & 21.00 & 4.00 & 29.30 & Oblong & White \\
\hline Collection 304 & 9.65 & 32.00 & 20.00 & 3.00 & 26.00 & Oblong & White \\
\hline Collection 314 & 11.44 & 34.00 & 24.00 & 4.00 & 10.90 & Oblong & White \\
\hline Collection 316 & 21.37 & 41.00 & 27.00 & 4.00 & 18.70 & Oblong & White \\
\hline Collection 320 & 10.47 & 34.00 & 22.00 & 4.00 & 20.10 & Oblong & White \\
\hline Collection 326 & 12.36 & 34.00 & 21.00 & 4.00 & 33.90 & Round & Purple \\
\hline Max & 22.60 & 41.00 & 27.40 & 5.00 & 44.60 & - & - \\
\hline Min & 6.71 & 28.00 & 19.00 & 3.00 & 9.60 & - & - \\
\hline Average & 11.91 & 33.48 & 22.98 & 3.94 & 22.47 & - & - \\
\hline CD (0.05) & 1.54 & 7 & 6 & 1 & 4.51 & - & - \\
\hline
\end{tabular}


Table 2. Clove characters of different garlic varieties and collections

\begin{tabular}{|c|c|c|c|c|c|c|}
\hline $\begin{array}{l}\text { Variety/ } \\
\text { collection No }\end{array}$ & $\begin{array}{l}\text { Clove } \\
\text { length } \\
(\mathrm{mm})\end{array}$ & $\begin{array}{l}\text { Clove } \\
\text { girth } \\
(\mathrm{mm})\end{array}$ & $\begin{array}{l}\text { Length/ } \\
\text { girth }\end{array}$ & $\begin{array}{l}\text { Clove } \\
\text { weight } \\
\text { (g) }\end{array}$ & Clove colour & $\begin{array}{l}\text { Clove } \\
\text { arrangement }\end{array}$ \\
\hline G1 & 16.5 & 5.80 & 2.84 & 0.40 & white & Regular \\
\hline G41 & 20.40 & 8.20 & 2.49 & 0.82 & white & Irregular \\
\hline G50 & 19.50 & 7.80 & 2.50 & 0.83 & white & Irregular \\
\hline G282 & 16.20 & 6.90 & 2.35 & 0.63 & Pinkish white & Regular \\
\hline G323 & 18.70 & 8.10 & 2.31 & 0.75 & white & Irregular \\
\hline GG2 & 17.00 & 5.60 & 3.04 & 0.40 & white & Regular \\
\hline GG3 & 14.80 & 5.60 & 2.64 & 0.39 & white & Regular \\
\hline Godavari & 15.50 & 7.60 & 2.04 & 0.57 & Purple white & Regular \\
\hline DARL50 & 16.80 & 6.80 & 2.47 & 0.53 & Pinkish white & Regular \\
\hline Collection 4 & 18.50 & 6.80 & 2.72 & 0.64 & White & Irregular \\
\hline Collection 6 & 17.60 & 6.50 & 2.71 & 0.51 & White & Irregular \\
\hline Collection 15 & 15.60 & 6.00 & 2.60 & 0.45 & White & Irregular \\
\hline Collection 43 & 13.30 & 7.70 & 1.73 & 0.87 & White & Irregular \\
\hline Collection 46 & 18.80 & 6.90 & 2.72 & 0.69 & Pinkish White & Irregular \\
\hline Collection 64 & 18.10 & 7.50 & 2.41 & 0.76 & Purple & Irregular \\
\hline Collection 79 & 22.10 & 6.70 & 3.30 & 0.79 & White & Irregular \\
\hline Collection 109 & 19.40 & 6.70 & 2.90 & 0.75 & White & Irregular \\
\hline Collection 162 & 17.90 & 6.40 & 2.80 & 0.68 & White & Irregular \\
\hline Collection 163 & 16.60 & 6.30 & 2.63 & 0.48 & Pinkish White & Irregular \\
\hline Collection 177 & 19.30 & 8.00 & 2.41 & 0.92 & Purple & Irregular \\
\hline Collection 215 & 17.20 & 7.50 & 2.29 & 0.88 & White & Irregular \\
\hline Collection 224 & 17.20 & 7.20 & 2.39 & 0.61 & White & Irregular \\
\hline Collection 227 & 17.60 & 8.20 & 2.15 & 0.58 & White & Irregular \\
\hline Collection 260 & 16.80 & 6.80 & 2.47 & 0.48 & White & Irregular \\
\hline Collection 273 & 18.50 & 7.80 & 2.37 & 0.87 & White & Irregular \\
\hline Collection 279 & 17.30 & 5.80 & 2.98 & 0.61 & White & Irregular \\
\hline Collection 286 & 16.30 & 6.20 & 2.63 & 0.45 & White & Irregular \\
\hline Collection 294 & 17.20 & 6.70 & 2.57 & 0.61 & White & Irregular \\
\hline Collection 301 & 16.90 & 7.80 & 2.17 & 0.67 & White & Irregular \\
\hline Collection 304 & 16.70 & 7.10 & 2.35 & 0.62 & White & Irregular \\
\hline Collection 314 & 17.50 & 7.90 & 2.22 & 0.80 & White & Irregular \\
\hline Collection 316 & 18.70 & 8.50 & 2.20 & 1.41 & White & Irregular \\
\hline Collection 320 & 16.80 & 7.10 & 2.37 & 0.61 & White & Irregular \\
\hline Collection 326 & 17.90 & 6.50 & 2.75 & 0.61 & Purple & Irregular \\
\hline Max & 22.10 & 8.50 & 3.30 & 1.41 & - & - \\
\hline Min & 13.30 & 5.60 & 1.73 & 0.39 & - & - \\
\hline Average & 17.49 & 7.03 & 2.52 & 0.67 & - & - \\
\hline CD (0.05) & 4.43 & 1.63 & 0.36 & 0.36 & - & - \\
\hline
\end{tabular}


$\mathrm{mm})$. The clove girth ranged from $5.60 \mathrm{~mm}$ to $8.50 \mathrm{~mm}$. It was higher in collection-316 (8.5 $\mathrm{mm})$ followed by collection-227, G-41 (8.20 $\mathrm{mm})$ and collection-314 $(7.90 \mathrm{~mm})$. Lower clove girth was recorded in GG-2, GG-3 (5.6 $\mathrm{mm})$ and collection-179, G1 $(5.8 \mathrm{~mm})$. The clove weight was in correspondence with the length and width of the clove. The data also revealed that collection-79, collection-279, G-1, collection-109 and GG-2 were slender while the collection- 43 had short and stout clove. The arrangement of clove was irregular in most of the genotypes. Only few genotypes such as G-1, GG-2, GG-3, Godavari and DARL-50 had regular arrangement of clove. Most of the clove varieties and collections were white in colour they were pinkish white in G 282, collection 46, collection 163, while it was purple in collection 64, collection 177, collection 326 and Purple white in cv. Godavari. The varieties with bigger cloves are usually high yielding and require less time for table and processing purposes hence, preferred in the market.

\section{Moisture and dry matter content}

The dry weight of garlic collections ranged from 28.6 per cent to 38.65 per cent (Table 3). It was highest in G-41 (38.65\%) followed by GG-2 (37.45\%), collection-109 (37.40\%) and collection 279 (36.8\%). Lower dry weight was recorded in collection- 4 (28.6\%), collection- 177 (29.2\%), collection-6 (29.60\%) and collection-64 (29\%). The moisture content was least in G-41 followed by GG-2, collection-109 and collection-279 (Table 3).

Total soluble solids, titrable acidity and ascorbic acid

The highest total soluble solids were found in collection $-79\left(35.1^{\circ}\right.$ Brix $)$, while higher total soluble solids were recorded in G-323 (32.99 Brix), collection -320 (32.9 $9^{\circ}$ Brix), DARL - 50 (32.54 $4^{\circ}$ Brix) and G-41 (32.4 ${ }^{\circ}$ Brix) compared to other genotypes. Lower total soluble solids were recorded in collection $-227\left(28.5^{\circ}\right.$ Brix $)$,

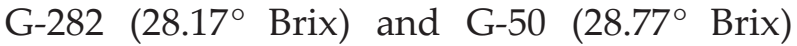
(Table 3$)$. There was no correlation between total soluble solids and dry matter content. The titrable acidity ranged from 0.72 per cent to 1.61 per cent. It was highest in collection-326 and collection-109 (1.61\%) followed by collection-15 (1.54\%) and Collection-163 (1.39\%). Among the released varieties, it was highest in cv. G-282 (1.22\%) followed by DARL$50(1.19 \%)$. The titrable acidity was lowest in cv. G-1 (0.72\%) followed by Collection-43 $(0.73 \%), \mathrm{G}-323(0.81 \%)$ and G-41 (0.83\%). There was no correlation among dry matter content, total soluble solids and titrable acidity (Table 3). The ascorbic acid content ranged from 13.8 $\mathrm{mg}$ to $33.80 \mathrm{mg} / 100 \mathrm{~g}$ fresh weight. It was highest in collection-260 (33.80 mg) followed by collection-162 $(29.9 \mathrm{mg})$ and lowest in GG2 (13.8 mg). Among the varieties, highest ascorbic acid was recorded in cv. DARL-50 (23.5 mg) followed by cv. Godavari (22.7 mg) (Table $3)$. The varieties and collections with higher total solid solids may be useful for processing purposes due to higher recovery.

\section{Macro and micro elements}

Among the nine varieties analyzed, nitrogen content ranged from 2.10 per cent to 3.0 per cent. It was higher in cv. Godavari $(3.0 \%)$, G-282 (2.80\%), G-1 (2.70\%) and G- 323 (2.70\%). Lowest nitrogen content was recorded in G-41 $(2.10 \%)$. The phosphorus content ranged from 0.90 per cent to 1.80 per cent. It was highest in DARL -50 (1.80\%) and lowest in GG-3 (0.90\%). Potassium content was highest in GG-2, (1.70\%) and lowest in G-41 and GG-3 (0.9\%). Sulphur content was higher in G-41 and GG-3 $(0.4 \%)$. The iron content was highest in GG-2 (47 ppm) and lowest in cv. Godavari (21.8 ppm). Manganese content ranged from 6.90 to $23.1 \mathrm{ppm}$. It was highest in G-41 and lowest in G-323. Zinc content was highest in GG-2 (19.2 ppm) and lowest in GG-3 (8 ppm). Copper content was highest in G-41. Higher content of minerals in small clove varieties was also reported by Islam et al. (2020). The results may be useful for selection of varieties with higher micronutrients for specific medicinal uses. 
Table 3. Chemical composition of different garlic varieties and collections

\begin{tabular}{|c|c|c|c|c|c|}
\hline Variety/ collection No & $\begin{array}{l}\text { Dry weight } \\
(\%)\end{array}$ & $\begin{array}{l}\text { Moisture } \\
(\%)\end{array}$ & $\begin{array}{l}\text { TSS } \\
\left.\text { ( }{ }^{\mathrm{O}} \text { Brix }\right)\end{array}$ & $\begin{array}{l}\text { Titrable } \\
\text { acidity } \\
(\%)\end{array}$ & $\begin{array}{l}\text { Ascorbic acid } \\
\left(\mathrm{mg} 100 \mathrm{gm}^{-1}\right)\end{array}$ \\
\hline G1 & 32.55 & 67.45 & 31.07 & 0.72 & 22.15 \\
\hline G41 & 38.65 & 61.35 & 32.40 & 0.83 & 13.65 \\
\hline G50 & 36.15 & 63.85 & 28.77 & 1.12 & 17.85 \\
\hline G282 & 32.05 & 67.95 & 28.17 & 1.22 & 14.35 \\
\hline G323 & 30.25 & 69.75 & 32.99 & 0.81 & 21.80 \\
\hline GG2 & 37.45 & 62.55 & 30.40 & 1.12 & 13.80 \\
\hline GG3 & 32.35 & 67.65 & 31.10 & 0.94 & 19.85 \\
\hline Godavari & 34.40 & 65.60 & 31.83 & 0.88 & 22.70 \\
\hline DARL50 & 33.80 & 66.20 & 32.54 & 1.19 & 23.50 \\
\hline Collection 4 & 28.60 & 71.40 & 28.20 & 1.10 & 20.80 \\
\hline Collection 6 & 29.60 & 70.40 & 31.10 & 1.03 & 29.00 \\
\hline Collection 15 & 35.00 & 65.00 & 28.90 & 1.54 & 20.80 \\
\hline Collection 43 & 31.20 & 68.80 & 28.70 & 0.73 & 26.90 \\
\hline Collection 46 & 34.40 & 65.60 & 28.00 & 1.03 & 27.30 \\
\hline Collection 64 & 29.00 & 71.00 & 29.80 & 1.32 & 25.10 \\
\hline Collection 79 & 34.60 & 65.40 & 35.10 & 1.03 & 22.10 \\
\hline Collection 109 & 37.40 & 62.60 & 30.30 & 1.61 & 21.70 \\
\hline Collection 162 & 35.20 & 64.80 & 28.80 & 1.25 & 29.90 \\
\hline Collection 163 & 30.00 & 70.00 & 31.90 & 0.95 & 20.40 \\
\hline Collection 177 & 29.20 & 70.80 & 30.60 & 1.25 & 28.60 \\
\hline Collection 215 & 30.80 & 69.20 & 29.10 & 1.10 & 21.20 \\
\hline Collection 224 & 30.80 & 69.20 & 32.30 & 1.17 & 21.70 \\
\hline Collection 227 & 34.20 & 65.80 & 28.50 & 1.10 & 27.30 \\
\hline Collection 260 & 34.60 & 65.40 & 30.10 & 1.03 & 33.80 \\
\hline Collection 273 & 32.80 & 67.20 & 29.70 & 0.95 & 21.70 \\
\hline Collection 279 & 36.80 & 63.20 & 31.10 & 1.03 & 21.70 \\
\hline Collection 286 & 31.40 & 68.60 & 32.50 & 1.03 & 24.30 \\
\hline Collection 294 & 33.50 & 66.50 & 28.70 & 1.03 & 19.50 \\
\hline Collection 301 & 32.00 & 68.00 & 32.90 & 1.39 & 28.20 \\
\hline Collection 304 & 33.40 & 66.60 & 29.70 & 1.03 & 19.90 \\
\hline Collection 314 & 31.40 & 68.60 & 28.70 & 1.10 & 21.70 \\
\hline Collection 316 & 34.40 & 65.60 & 29.70 & 1.10 & 25.10 \\
\hline Collection 320 & 32.40 & 67.60 & 32.90 & 1.03 & 23.40 \\
\hline Collection 326 & 33.40 & 66.60 & 28.90 & 1.61 & 23.80 \\
\hline Max & 38.65 & 71.40 & 35.10 & 1.61 & 33.80 \\
\hline Min & 28.60 & 61.35 & 28.00 & 0.72 & 13.65 \\
\hline Average & 33.05 & 66.95 & 30.46 & 1.10 & 22.81 \\
\hline $\mathrm{CD}(0.05)$ & 2.71 & 4.83 & 1.90 & 0.42 & 2.51 \\
\hline
\end{tabular}




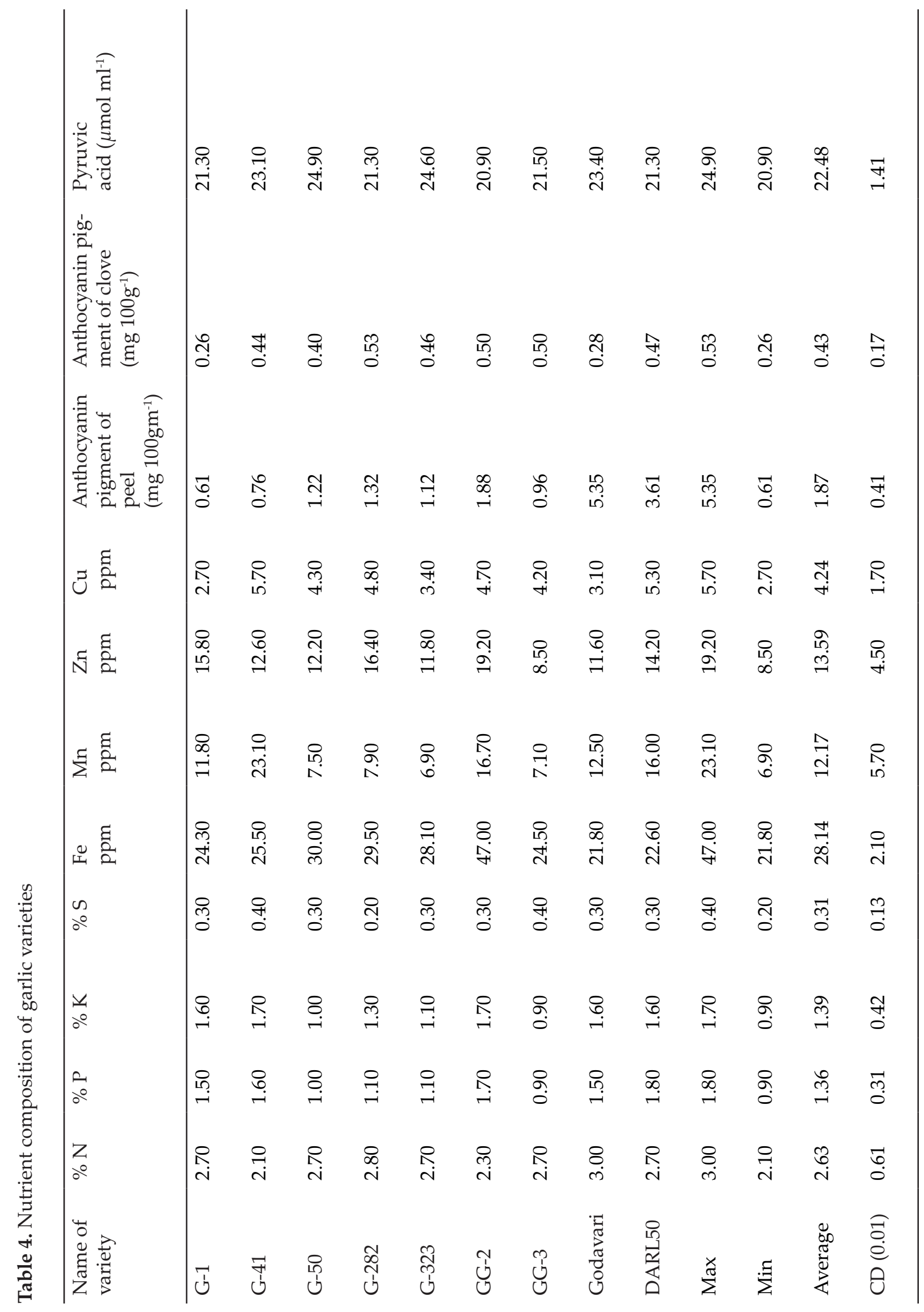




\section{Anthocyanin and pyruvic acid}

As far as the colour pigments are concerned, highest anthocyanin pigment was found in the peel of $\mathrm{cv}$. Godavari (5.35 mg) followed by $\mathrm{cv}$. DARL-50 (3.61 mg). It was least in white colour varieties. There was not much difference in anthocyanin content in pulp of purple colour varieties and white colour varieties. It was highest in G-282 (0.53 ppm). DARL-50 had 0.47 ppm while Godavari had only $0.28 \mathrm{ppm}$. The pyruvic acid content ranged from 20.9 to 24.9 $\mu \mathrm{mol} \mathrm{ml} \mathrm{m}^{-1}$. It was higher in G-50 (24.9), G-41 (32.1), G-323 (24.9) and Godavari (24.5 mg) (Table 4).

The data revealed wide variability in garlic genotypes with varying morphological and biochemical characteristics. There are no definite trends of higher nutritive values in the small clove garlic collections. The nutritive value of coloured garlic varieties and white coloured varieties was almost similar except for the higher anthocyanin content in the peel in coloured varieties. Results revealed that genotypes G-50, G-41 and collection-316 were better than other genotypes with respect to morphological and biochemical characteristics.

\section{References}

Anna B, Giulia C, Corrado L, Pasqua L, Giuseppe, Ambacorta \& Antonio E 2020 Evaluation of Garlic Landraces from Foggia Province (Puglia Region; Italy). Foods 9: 850.

Anonymous 2018 Horticultural Statistics at A Glance, Horticulture Division, Ministry of Agriculture \& Farmers' welfare, Government of India, 458p.

Bhattacharjee S 2013 Analysis of the proximate composition and energy values of two varieties of onion (Allium cepa L.) bulbs of different origin: A Comparative Study. Int. J. Nutr. Food Sci. 2: 246.

Danna D, Lapichino F G \& Miceli A 2000 Effect of clove weight on yield and bulb quality of garlic grown for storage. Acta Hortic. 533: 589-592.

Gebreyohannes G \& Gebreyohannes M 2013 Medicinal values of garlic: A review. Int. J. Agric. 5: 401-408.
Giusti M M \& Wrolstad R E 2001 Characterization and measurement of anthocyanins by UVVisible spectroscopy. Cur. Protocols in Food Anal. Chem. F1.2.1-F1.2.13.

Gupta R P 2015 A step towards increasing garlic productivity. Cur. Sci. 108: 1414-1419.

Islam D, Lina N N, Roy R K, Chadni L, Zubayed A, Samina A, Liton C M, Evena P L, Mahmuda H \& Dipankar C R 2020 Relative proximate composition and mineral analysis of three garlic varieties available in Bangladesh. Europ. J. Med. Plants 31: 1-9.

Panse V G \& Sukhatme P V 1995 Statistical methods for agricultural workers. ICAR, New Delhi, 359p.

Piper C S 1966 Soil and plant analysis, Hans Publishers, Bombay, 368p.

Rana S V, Pal R, Vaiphei K, Sharma S K \& Ola R P 2011 Garlic in health and disease. Nutr. Res. Rev. 24: 60-71.

Ranganna S 1986 Handbook of analysis and quality control for fruit and vegetable products, Tata McGraw-Hill Publishing Company Lt. New Delhi, 1112p.

Rivlin R S 2001 Historical perspective on the use of garlic. J. Nutr. 131: 951S-954S.

Tattelman E 2005 Health effects of garlic. Am. Fam. Physician. 72: 103-106.

Tripathi P C, Sankar V \& Lawande K E 2013 Medicinal and theuraptic value of garlic. Spice India Dec. 14-16.

Woodward P W 1996 Garlic and friends: the history, growth and use of edible Alliums. Hyland House, Melbourne.

Yebirzaf Y, Belete N, Tegibew W, Yohaness G, Abayneh M \& Kassahun Y 2018 Collection and characterization of garlic (Allium satiom L.) germplasm for growth and bulb yield at Debre Markos, Ethiopia. J. Hort. For. 10: $17-26$.

Yoo K, Sun P, Leonard M \& Hamilton B K 1995 Astuplitied pyruvic acid analysis suitable for onion breeding programs. Hort. Sci. 30: 1306. 